\title{
Application of Multichannel Access and Customer Journey Map in the Context of Innovative Business Projects
}

\author{
Kristina Retkutè, Vida Davidavičienė \\ Vilnius Gediminas Technical University, Faculty of Business Management, \\ Saulètekio al. 11, LT-10223 Vilnius, Lithuania \\ kristina.retkute@gmail.com ${ }^{1}$,vida.davidaviciene@vilniustech.lt ${ }^{2}$
}

\begin{abstract}
The rapid spread of financial technologies was significantly affected by the 2008 economic crisis. During the crisis, people's confidence in banking was severely weakened. The decisions taken by the banks were blamed for the economic crisis. At the same time, new technologies (such as blockchain technology, artificial intelligence, alternative payments, etc.) have emerged or reached maturity, bringing competitive prices and quality of service to the market, as well as the proliferation of smartphones made technologies easily accessible to consumers. The innovative projects were started to grow. One of the most innovative fields of business became the financial technology sector. The fintech sector created a variety of innovative business projects that became big and famous companies. The fintech sector, like most other innovative businesses, is engaged mainly in the provision of remote services. This mode of service has reached its maturity during the Covid-19 global pandemic. Nowadays, remote customer service has taken on a new meaning and quality in the world. Most companies provide remote customer consultations (video calls, correspondence on various online platforms, etc.), customers have conditions to receive goods or services with as little contact between individuals as possible. The Fintech sector had already gained experience in this type of customer service because most of the businesses in the sector had the experience of this type of customer service before the global pandemic. The article examines the global development of fintech, the main multichannel access channels in the fintech sector, the relevance of customer life cycle and customer journey in the fintech sector, the customer's experience from the customer's journey perspective in the fintech sector. Methodology and results of the organized research are presented in the article. The customer's life cycle matrix and customer's journey map are created in the article.
\end{abstract}


Keywords: Customer life cycle, multichannel access, digital access, innovative projects, remote access, fintech, digital channels, customer journey map, digital media.

\section{Introduction}

Companies in the Fintech sector tended to choose electronic channels for advertising to reach the customer and advertise even before the pandemic. This type of advertisement focuses on the target consumer - the person interested and using innovative technologies (Sahay et al., 2020). Regarding meant facts fintech sector is closely linked to the existence of electronic media. The organization has great potential for fast and convenient advertising, and the customer is given the opportunity for effective communication and problem-solving. With the global Covid-19 crisis in 2020, the media has become particularly important for daily tasks. Learning was ported to remote channels; most people started working from home with the help of a variety of media. Some groups of people have become highly marginalized (individual high-risk groups), so communication through the media has become the only way to communicate between different people (Abel \& McQueen, 2020). Shopping has largely shifted to remote channels as the society is ordering online and trying to avoid contact or obtaining relevant goods due to the pandemic, making multichannel access and e-media a daily task for most businesses to stay afloat, and the fintech sector making payments and other financial services much easier than banks to both legal and natural persons (Christi \& Barberis, 2016). Due to the exceptional situation in the world and the rapid use of innovative technologies in this situation, the study is particularly relevant for both existing or potential customers in the sector and fintech organizations. The study aims to analyze the challenges, opportunities, and research directions of multichannel marketing in the financial technology sector and create a customer journey map for electronic money institutions.

Before the epidemiological crisis, the problem related to this work, especially during it, is that a large part of society fulfills their daily needs online (online communication, shopping, reading news, listening to music, etc.). With a large supply, consumers become picky when choosing goods or services. In the $21 \mathrm{st}$ century, consumers are in a hurry and can spend less time shopping physically. Most modern consumers choose the physical shopping process as meeting social and emotional needs, in other words, as entertainment rather than as a goal (Pantano \& Viassone, 2015). Regarding this hypothesis, organizations need to develop channels and find a way to reach the customer, and make shopping as easy and convenient as possible. It is also essential for organizations to know the customer's journey through organization offers before and after the purchase or contract. Each interaction point with the customer is vital for decision-making and loyalty. Regarding the mentioned statements of the analysis of scientific researches 
regarding this issue, it has been found that there is a lack of research in the scientific literature on the application of electronic media and multichannel access in the Fintech sector. Regarding the lack of scientific studies on this topic, it has been found that in the financial market, the fintech sector has given meaning to the essence of e-media as a basis for the whole industry. Based on this information, it has been concluded that this type of study is necessary and appropriate in the scientific literature. The novelty of the sector and Covid-19 makes the research highly relevant. Therefore, a region was chosen for the study to optimize the scope of the study. While selecting the study region, various circumstances were assessed: the country's competitiveness in the sector, the growth of the number of companies, the suitable regulatory environment, etc. Lithuania was selected for the research based on these circumstances, which are characterized by the rapid growth of the fintech sector. Lithuania is competitive for various reasons: the highly favorable regulatory environment for the fintech sector, the large number of qualified employees, the advantageous geographical location, etc. In Lithuania, the fintech industry's growth has been noticeable since 2013, but it has been established rapidly since 2016. More than 230 fintech companies are currently operating in different fields in Lithuania (Invest Lithuania, 2021). Since the beginning of fintech development (2016), two fintech associations, Fintech hub Lt and Fintech Lithuania have been established in Lithuania, which helps market participants adapt to the Lithuanian market and provide an opportunity to communicate and share knowledge. (Invest Lithuania, 2019). The research methods are scientific literature and data analysis, survey, creation of customer travel matrix, and customer travel map.

\section{Literature Review}

By analyzing statistics and research, there has been a rapid growth in applying financial technologies in various fields (see Figure 1) (Statista, 2020). According to Earnst \& Youg, between 2015 and 2019, global fintech adoption increased by 44 percent (EY, 2019).

In order to assess the scientific uncertainty and behavioral patterns of e-media and multichannel access applications in the fintech sector, as well as the advantages of e-media and multichannel access application due to the specificity of the fintech sector, it is appropriate to introduce research/achievements in multichannel marketing. Multichannel marketing is an individualized approach to marketing that uses many different channels and media. The main idea is to capture the audience's attention uniquely and memorably. Multichannel marketing is a method of communicating with customers through a combination of indirect and direct communication channels - internet websites, e-mail, direct mail, retail stores, mobile apps, etc. it can be any channel (online or direct) through which one can reach the consumer, introduce him to a product or service, attract him to buy and 
turn him into a loyal consumer (The Vomela companies, 2017). According to Rhee, direct marketing has sought to shift a large part of marketing to the Internet, and social networks as the opportunities offered by the Internet arise, as it makes it easier and faster to reach the consumer and requires significantly lower costs for advertising dissemination (Rhee, 2009). Chaffey et al. state that acquiring new customers keeping in touch with them, and ensuring its successful operation in the Internet space makes it necessary to use multichannel access (Chaffey \& EllisChadwick, 2019). A multichannel marketing strategy should be based on the company's product or service and what target audience it targets. This is where the question arises as to whether this applies in all cases and what behavior patterns can lead to science-based decisions for efficiency.

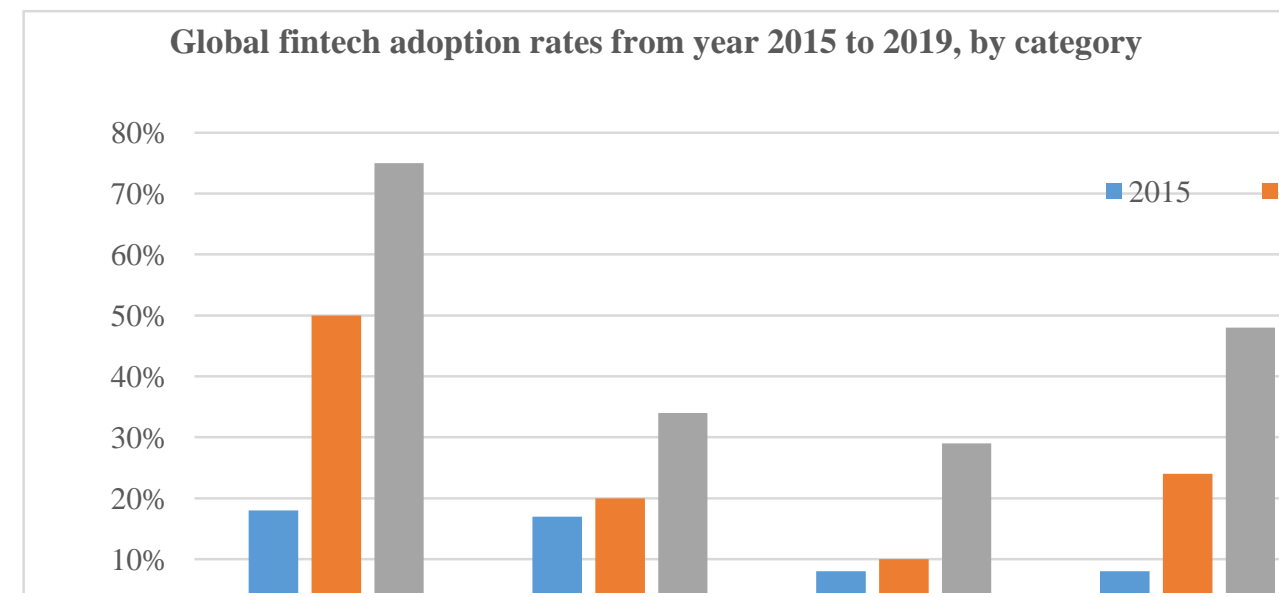

Fig. 1: Global fintech adoption rates from the year 2015 to 2019 by category (Statista, 2020)

Customers travel through virtual channels choosing the products that are relevant to them and thus interact with brands. The customer does not use the Internet as a separate means to buy; the customer uses various media, media, and social networking to get to know and reach the product. This statement provides the basis for the planned investigation. It is essential to mention that older people still tend to use obsolete media such as television, newspapers, and radio. However, they and $\mathrm{z}$ generations spend a large part of their time in cyberspace and therefore have an advanced habit of searching for information and wares online. All of these different channels created to reach the consumer are part of multichannel marketing. The very process by which a customer finds a favorable path to a product is called a customer journey. Creating a company's convenient access through different channels is multichannel marketing (Peterson, Gröne, Kammer, \& Kirscheneder, 2010). Multichannel marketing is especially important for companies that operate only online (Liu \& Yang, 2016) in their study highlighted the growth rate of digital communication channel use (e.g., mobile phone calls, text messaging, social 
networks), as well as the importance of their selection and the need for appropriate attention to consumer behavior. Thus, considering the specifics of the fintech sector and the recommendations of scientists, it is reasonable to focus on digital marketing when analyzing multichannel marketing because the journey of a client in the fintech sector follows through e-media-based channels; in this work, more examined detail of the electronic media that are most used and implemented in the fintech sector.

Table 1: Electronic media applications opportunities and application uncertainties (created by the Authors based on Key, 2017; Hwang, Lin, \& Shin, 2018; Chaffey \& Ellis-Chadwick, 2019; Iskandar \& Komara, 2018)

\begin{tabular}{|c|c|c|}
\hline Media & Aplication & Challenges / uncertainties \\
\hline E-mail & $\begin{array}{l}\text { E-mail is typically used in the analysis } \\
\text { phase. The customer orders a subscription } \\
\text { with interest and in the purchase phase when } \\
\text { the payment invoice arrives in the customer's } \\
\text { e-mail. In addition to the features listed, e- } \\
\text { mail is widely used in the loyalty phase, } \\
\text { where the customer maintains a business } \\
\text { relationship with the organization. Marketing } \\
\text { through E-mail marketing is a marketing } \\
\text { technique that connects informational, } \\
\text { promotional, and customer relationship } \\
\text { management. }\end{array}$ & $\begin{array}{l}\text { For e-mail customization to } \\
\text { the organization, the company } \\
\text { needs to create or acquire a list } \\
\text { of recipients created from the } \\
\text { organization's past, present, or } \\
\text { base of potential customers. } \\
\text { One of the positive aspects of } \\
\text { e-mail database management is } \\
\text { harnessing the potential of } \\
\text { segmentation to create topical } \\
\text { content and advertising based } \\
\text { on criteria such as age, gender, } \\
\text { or history of a purchase (Key, } \\
\text { 2017). }\end{array}$ \\
\hline $\begin{array}{l}\text { Social } \\
\text { media }\end{array}$ & $\begin{array}{l}\text { This e. the media channel is one of the most } \\
\text { commonly used digital marketing channels } \\
\text { to create products with minimal advertising } \\
\text { costs. Social media is used at all stages of } \\
\text { the customer's life cycle as it is a virtual } \\
\text { space where the user spends a lot of time } \\
\text { compared to other channels. Social media } \\
\text { enables both small and large businesses to } \\
\text { attract new customers and reach existing } \\
\text { customers more effectively. Social media } \\
\text { provides an opportunity to reach a new target } \\
\text { audience, increase productivity and } \\
\text { efficiency and improve growth and } \\
\text { competitiveness. Social media has become a } \\
\text { relevant part of the branding and an } \\
\text { organization's marketing communication. } \\
\text { Facebook, Twitter, Instagram have become } \\
\text { vital channels for engaging consumers and } \\
\text { building brand awareness (Hwang, Lin, \& } \\
\text { Shin, 2018). There is also some form of } \\
\text { social media in which a company maintains } \\
\text { a reasonably high level of control. The blog }\end{array}$ & $\begin{array}{l}\text { Although most society uses } \\
\text { social networks, there is still a } \\
\text { possibility that potential } \\
\text { customers may not use social } \\
\text { media, which raises the } \\
\text { question of how to attract } \\
\text { people who do not use social } \\
\text { media channels but may also } \\
\text { be potential customers of } \\
\text { fintech companies. }\end{array}$ \\
\hline
\end{tabular}




\begin{tabular}{|c|c|c|}
\hline & $\begin{array}{l}\text { is usually on the company's website, } \\
\text { allowing content to be edited and comments } \\
\text { to be tracked and filtered. Social media is a } \\
\text { successful tool for brand building and } \\
\text { customer engagement and building unique } \\
\text { customer relationships. }\end{array}$ & \\
\hline $\begin{array}{l}\text { Mobile } \\
\text { applicati- } \\
\text { ons }\end{array}$ & $\begin{array}{l}\text { This e. the media has spread very rapidly } \\
\text { since } 2010 \text {. Mobile apps are most commonly } \\
\text { used in the customer lifecycle stages of } \\
\text { analysis, purchase, retention, and loyalty. } \\
\text { Customers usually start using apps when } \\
\text { they are familiar with the product and are } \\
\text { already involved. Mobile applications } \\
\text { provide the ability to integrate many features } \\
\text { that help overcome inconvenience to } \\
\text { customers. Mobile apps have many valuable } \\
\text { components that are needed to facilitate the } \\
\text { use of the apps, such as ratings with which } \\
\text { the apps and their content can be rated; such } \\
\text { features increase customer confidence in the } \\
\text { product. In-app messages can be used for } \\
\text { direct and indirect advertising. This is one } \\
\text { reason why the use of mobile applications } \\
\text { has increased (Chaffey \& Ellis-Chadwick, } \\
\text { 2019). }\end{array}$ & $\begin{array}{l}\text { Although the marketing } \\
\text { literature is still focused on } \\
\text { research into the use of mobile } \\
\text { applications, it is expected that } \\
\text { apps as a digital marketing } \\
\text { channel will be increasingly } \\
\text { used in the future. The key } \\
\text { aspects of using apps as a } \\
\text { digital marketing channel are } \\
\text { trust, usefulness, and user } \\
\text { experience. However, } \\
\text { uncertainty remains at this } \\
\text { point, as applications are } \\
\text { thought to have not yet } \\
\text { reached its peak. }\end{array}$ \\
\hline $\begin{array}{l}\text { Internet } \\
\text { search } \\
\text { apps }\end{array}$ & $\begin{array}{l}\text { This e. the media measure is most commonly } \\
\text { used in the discovery and analysis stages. } \\
\text { The customer searches for goods or products } \\
\text { and then finds an organization that provides } \\
\text { the customer's goods, products, or services. } \\
\text { When a user enters a query into the search } \\
\text { box, they get three types of results - those } \\
\text { that are reasonable are relevant, those that } \\
\text { conform to the system algorithm, and those } \\
\text { that are paid. }\end{array}$ & $\begin{array}{l}\text { To manage an effective SEO } \\
\text { (search engine optimization) } \\
\text { strategy, you need a detailed } \\
\text { understanding of search } \\
\text { engines used by search engines } \\
\text { such as Google, Bing, and } \\
\text { Baidu. An SEO strategy is } \\
\text { used to maximize the display } \\
\text { of content (Iskandar \& } \\
\text { Komara, 2018). }\end{array}$ \\
\hline
\end{tabular}

Based on the table above, the study will be conducted through the prism of these four channels. By using the application possibilities and the listed uncertainties, a survey was conducted to clarify the efficiency of the listed channels in individual stages of the client's journey.

Relevance of customer life cycle, customer jourey and e-media in the fintech sector. The customer life cycle is a critical object to create a customer journey map. The customer life cycle is different in different organizations, so it is very important to find out the nuances of the customer life cycle in a particular sector or company in the research to create an effective customer journey map. This article focuses on fintech customer journey mapping, as the links between this sector, multichannel marketing, and customer journey are not sufficiently analyzed in the scientific literature. 
The customer's life cycle typically begins when the customer needs a product and/or service and continues to the interaction point where the product will be purchased, and the customer will already have an opinion about the product and organization. The organization's goal is to manage customer journeys to maximize worth for both the client and the organization. The customer journey can be described as a systematic approach that helps organizations understand how current customers use different channels and interaction points, how they perceive the organization at each interaction point, and how they would like the organization to communicate with them (Nenonen, Rasila, Junnonen, \& Karna, 2010). In the scientific literature, it is recommended to use five stages of the client's life cycle, according to which the points of contact are determined (Cowman, 2018):

1) Discovery stage - in this stage, the customer first sees the company/product/service, gets acquainted with it;

2) Analysis stage - in this stage, the client is interested in the company's activities and provided services and may be interested in the product or service;

3) The purchase stage is the stage at which the purchase/sale takes place;

4) The maintenance stage is this stage during which the customer evaluates the quality of the received product/service and makes a decision;

5) Loyalty stage - this stage aims at long-term customer involvement and maintaining long-term relationships.

The customer's life cycle follows the actual implementation of this cycle and its application in the organization. To assess the customer's life cycle, visualize the results of this purpose, the visual tool is often used after analyzing the results of customer behavior - the customer's travel map.

Researchers identify the customer journey map as documents that visually illustrate the customer's behavioral processes, needs, and perceptions throughout their relationship (Bruce, 2010). The customer journey is identified as the customer interaction cycle. It is a visual, process-oriented approach to conceptualizing and structuring customers. Customer travel maps consider people's mental patterns (how they behave) and possible points of contact. They can integrate user profiles, scenarios, and user flows and reflects customer experiences, opinions, paths, and experiences (Nenonen et al., 2010). Some authors view the client's journey as an operational and effective tool to address these barriers (Dadiv C. Edelman \& Singer, 2015). Identifying the actions that customers take when interacting with a company can actually take the customer's perspective into account. A deep understanding of the client's world is essential to understanding the client's interests. Properly researched customer travel provides customers with an excellent customer experience (Bolton et al., 2013). The customer journey is a process-oriented diagram that outlines the company's key steps to engaging the customer. As a result, customers are attached to the company and its brand (Buijs, Bergmans, \& Hasnaoui, 2019). Customer journey is an essential but straightforward tool to help you learn 
about the customer experience.

The customer journey is related to the customer experience, which is defined as the entire path of direct and indirect communication between customers and the company through multichannel access, which determines the customer's cognition, perception of emotions, and behavior (Lemke, Clark, \& Wilson, 2011). For this reason, a client's trip can also be applied to pervasive research. Second, the customer journey explores the entire interactive process that begins before purchase; when, for example, consumers are confronted with advertising, the act of attention and purchase occurs, continues with consumption and experience, and ends when the experience disappears (Addis, 2016).

Despite theoretical knowledge, a client's journey map poses many challenges for both practitioners and researchers. For this reason, when creating a customer journey map, the sheets are essential to find out the factors that will guide further research in this work. According to the decision made by the authors, the aspects proposed by Addis (2016) are applied in work, as they are properly adapted to evaluate the experience of fintech customers (Addis, 2016):

1) What is the customer experience, and what does it mean to him (this can be both existing and potential customers)?

2) What are the main points of contact in communication with the client?

3) What are the main ways customers get service?

4) How do customers interact with the physical environment and company representatives?

5) What are the benefits to the customer?

6) What are the barriers that cause customer dissatisfaction?

7) How can each interaction be improved to make the customer experience a good one?

In order to clarify the essential issues, various sources should be used - feedback of social networks, customer surveys, statistics, etc. In most aspects, a customer journey map is a creative process that requires data analysis and ingenuity.

Although many articles discuss customer journey mapping, both scholars and professionals still question the best models for modeling the journey of consumer decisions (Moon, Han, Chun, \& Hong, 2016). The customer travel map concept lists all possible customer and organization contact points that customers encounter when exchanging services (Rosenbaum, Otalora, \& Ramírez, 2017). The contact points on the customer's journey maps are usually displayed horizontally, according to the time zone of the process, i.e., according to the customer's stage. The time is divided into three periods: service before the main service, service during the main service, and service after the main service. The pre-service period refers to the customer's experience before the service begins. During the basic service, the period of service is related to the points of contact those customers experience during the actual service. The after-service period reflects the customer's post-service 
experience.

Table 2: Customer service experience (created by the authors based on Voorhees et al., 2017)

\begin{tabular}{|l|l|l|}
\hline \multicolumn{3}{|c|}{ Service experience } \\
\hline Service before basic service & Maintenance service & \multicolumn{1}{|c|}{ Main service } \\
\hline - Communication & - Key points of & - Main service; \\
- Search of information & interaction (employees; & - Restoration of service; \\
(access to the competitor's & other customers; & - Customer feedback \\
tebsites: access to a third & technologies) & (Surveys to the customer \\
party websites; online and real & - Environment. & about the quality of service \\
recommendations & & $\begin{array}{l}\text { - Response; } \\
\text { - Intitial contact(Face to face; } \\
\text { telephone; internet) }\end{array}$ \\
& & $\begin{array}{l}\text { - Involving customers in } \\
\text { developing new service; }\end{array}$ \\
& & - Recommendations \\
\hline
\end{tabular}

Customer service experience is an important part of a customer's journey, as their decisions depend on the customer's experience. If the customer is improperly served at one of the stages, there is a chance that the customer may refuse the product. There are three main stages: pre-contract service, maintenance service, and postcontract service. Pre-contract service can be both contact and virtual, but the main things a potential customer does are evaluate the information and the expected benefits. When concluding the contract, the customer values the more sensitive information to the customer, for example: product price, data security, and obligations to itself. If the customer has uncertainties or shortcomings in obtaining information, the contract may not be concluded. Post-contract service is a crucial aspect in making a customer loyal and engaging. At this stage, minimal organizational mistakes are more easily forgiven than at previous stages because the customer is already more engaged than at other stages. Customer experience and engagement could deepen customer engagement in recommendations to the organization (Voorhees et al., 2017). From this information, the question arises as to how the situation is managed in the fintech sector, and based on these findings; the study will assess information related to customer feedback and recommendations on the channels used by companies in the fintech sector and experiences at individual stages of the customer's journey.

\section{Research Methodology}

Literature analysis revealed a lack of literature in the creation of client travel maps in specific sectors. Furthermore, there is a lack of literature on the interfaces between multichannel access, customer journey, and the fintech sector. According to the authors, the fintech sector is currently one of the fastest-growing sectors, and 
the use of multichannel access is very relevant for this sector. Based on these gaps in the literature, the authors conducted research to identify a specific situation in a specific sector, which will result in conclusions and suggestions for fintech organizations to improve customer service at individual stages of the customer journey. In order to clarify the application of multichannel access in the fintech sector and to framework a customer journey map in fintech e. money/ payment institutions, research was created using the survey method (the results of the survey are presented below). The research examined the survey results and identified the channels through which customers access selected fintech e. money/payment institutions, the interaction points of contact, and how customers communicate with e. money/payment institutions. By using the results of theoretical and empirical research, a customer life cycle matrix and a customer journey map were created. Survey to take - 376 natural persons. The survey method was conducted anonymously in the online space. The surveys were distributed throughout Lithuania to Lithuanian citizens of all ages, originating and living in different regions of Lithuania and receiving different amounts of income. Questionnaire questions type is the test and open questions.

The survey questionnaire consists of 15 questions that help to evaluate the experience of customers of e.money / payment organizations customers, what are the interaction points between the customer and the company, as well as the channels through which customers learned about the services provided by these organizations, through which customers purchased goods or services offered by the organization; Links to the survey were disseminated through social networks and by contacting respondents directly.

According to which further research is carried out - a creation of the customer travel matrix and customer journey map. The survey used a questionnaire that asked general questions needed to determine the respondent's gender, age, education, income, and place of residence. Respondents requested whether respondents have used fintech e. money/payment institution services now or in the past. As the questionnaire is targeted at the target audience of customers who have not used e. money / payment institutions, respndents were requested to complete the survey. Respondents were asked what kind of e. money/payment institutions they have had used. Another question was how existing customers found out about e. money/payment institutions, i.e., by what channels the company has reached its customer and what is the first interaction point. The survey also identifies why customers started using the services provided by e. money/payment institutions. It is important to find out this because it determines the company's unique features that attracted consumers and explain 2 interaction points that led the customer to conclude the contract. The following question asks respondents about postcontractual communication with e. money/payment institutions. This question aims to examine which channels operate most efficiently in the retention phase and the 
3rd interaction point. In the survey, respondents are asked if they are satisfied with the goods or services offered by the organization; if respondents are dissatisfied, they could mention what they are not satisfied with. Then a 4th interaction point is determined. Respondents in the survey are requested about good and bad experiences using e. money/ payment institutions services. The aim is to find out the disadvantages and advantages of the company. The survey further identifies the experiences of former customers and the reason for the disconnection with the company; these answers could clarify the 5th interaction point, which reveals the shortcomings of the organization and created conditions for the customer, which led the customer to refuse the company's services.

Based on the analysis of the literature and the results of the survey, the illustrated customer life cycle matrix and customer journey map are presented. Customer journey maps are often considered flawed if they are created for all customers in an organization because all customers in the organization are different, have different needs and habits, are affected differently by each stage, and have different points of contact with the organization (Rosenbaum et al., 2017). Based on this hypothesis, a customer life cycle matrix will be made based on the highest concentration of respondents in the survey, which was determined by respondents answering general questions. The client's travel map is visualized by using the ww.draw.io website.

Customer journey map creation sources are:

- The customer journey map presented in the article shows five main stages of the customer's life cycle, which were identified in the theoretical part of the work.

- The client's journey map presented the client's steps at each stage; the steps were determined after the survey.

- The customer journey map presented in the article provides interaction points at each stage of the customer life cycle. Interaction points were determined by literature analysis, survey, and customer travel matrix.

- The customer journey map presented in the article provides organizations with suggestions on which departments could solve the current problems in the organization or which departments could contribute to maintaining and improving a quality product/service. This data is derived from publicly available information on the functions performed by the different departments. It is essential to mention that the departments mentioned in the customer travel map do not necessarily exist in all the e-mails studied. For example, in e. money/payment institutions, but following research, these departments assess the need to provide quality goods/services to the customer or the benefits of improving or maintaining the quality of services.

\section{Results of the Research and Customer's Journey Map}

According to the author's survey, most Revolut customers participated in the survey. 
Most respondents learned about the organizations through relatives/friends/acquaintances, which suggests that most users feedback from relatives/friends/acquaintances. The main reasons for starting to use the services were the relevance and innovativeness of the provided services. Customers cited various constraints and quality of service as the main shortcomings of fintech organizations, suggesting that the relatively new sector is not yet sufficiently skilled in these areas. Customers identified mobile apps and e-mail as the main channels in post-contractual service. As a result, the main post-contractual service channels are noticeable.

Table 3: Survey results (created by the authors based on survey results)

\begin{tabular}{|c|c|c|c|c|c|c|c|}
\hline \multicolumn{8}{|c|}{ Fintech e. money/ payment institutions used by the respondents } \\
\hline $\begin{array}{l}\text { Payment } \\
\text { institution }\end{array}$ & Revolut & Paysera & Monese & TransferGo & \multicolumn{2}{|c|}{$\begin{array}{c}\text { TransferWis } \\
\text { e }\end{array}$} & Other \\
\hline $\begin{array}{l}\text { Distribution of } \\
\text { respondents }(\%)\end{array}$ & 56 & 22 & 10 & 8 & \multicolumn{2}{|c|}{2} & 2 \\
\hline \multicolumn{8}{|c|}{ Channels through which respondents learned about services offered by Fintech e. money/payment institutions } \\
\hline Channel & $\begin{array}{c}\text { Social } \\
\text { networks }\end{array}$ & \multicolumn{2}{|c|}{$\begin{array}{c}\text { relatives / friends / } \\
\text { acquaintances }\end{array}$} & $\begin{array}{c}\text { Through television, } \\
\text { press, radio }\end{array}$ & \multicolumn{3}{|c|}{ Per internet explorer } \\
\hline $\begin{array}{l}\text { Distribution of } \\
\text { respondents }(\%)\end{array}$ & 38 & \multicolumn{2}{|c|}{56} & 3 & \multicolumn{3}{|c|}{3} \\
\hline \multicolumn{8}{|c|}{ Reasons why respondents started using Fintech e. money/payment institution services } \\
\hline Reasons & $\begin{array}{c}\text { Attractiveness } \\
\text { of the } \\
\text { innovativenes } \\
\text { s of the } \\
\text { services } \\
\text { provided }\end{array}$ & $\begin{array}{l}\text { Attractiv } \\
\text { eness of } \\
\text { the } \\
\text { services } \\
\text { offered }\end{array}$ & $\begin{array}{c}\text { Attractiveness } \\
\text { of the idea of } \\
\text { organization }\end{array}$ & $\begin{array}{l}\text { Attractiveness of the } \\
\text { exceptional } \\
\text { opportunities } \\
\text { (virtual currencies, } \\
\text { financial planning, } \\
\text { etc.) }\end{array}$ & $\begin{array}{c}\text { Just } \\
\text { wanted } \\
\text { to try }\end{array}$ & & ttractive rates \\
\hline $\begin{array}{l}\text { Distribution of } \\
\text { respondents }(\%)\end{array}$ & 26 & 26 & 17 & 13 & 15 & & 3 \\
\hline \multicolumn{8}{|c|}{ Factors unsatisfying customers of fintech e-money/payment institutions } \\
\hline Factors & $\begin{array}{l}\text { Service } \\
\text { quality }\end{array}$ & \multicolumn{2}{|c|}{ Lack of security } & Various restrictions & \multicolumn{3}{|c|}{$\begin{array}{c}\text { Application of additional } \\
\text { charges }\end{array}$} \\
\hline $\begin{array}{l}\text { Distribution of } \\
\text { respondents }(\%)\end{array}$ & 31 & \multicolumn{2}{|r|}{24} & 33 & \multicolumn{3}{|c|}{11} \\
\hline \multicolumn{8}{|c|}{ Channels with which respondents interacted with Fintech e. money/payment institution staff } \\
\hline Channels & E-mail & \multicolumn{2}{|c|}{ Through mobile phone } & Social networks & $\begin{array}{c}\text { Mobile } \\
\text { app }\end{array}$ & & $\begin{array}{l}\text { ommunicating } \\
\text { vith a virtual } \\
\text { consultant }\end{array}$ \\
\hline $\begin{array}{l}\text { Distribution of } \\
\text { respondents (\%) }\end{array}$ & 29 & \multicolumn{2}{|c|}{14} & 25 & 30 & & 2 \\
\hline
\end{tabular}

Based on the results of the survey and literature analysis, a customer life cycle matrix was developed. The literature analysis illustrates the columns of tasks and questions; the empirical research demonstrates the columns of points of contact, emotions, and weaknesses. Although according to the hypothesis presented in the methodological part, a specific group of clients must be selected to illustrate her client's journey properly. The study further examines the largest group of clients' women aged 18-25, with higher education and high incomes. These two customer 
groups are further explored in this study. The customer life cycle matrix and customer travel map are constructed based on the habits and characteristics of these customer groups. The customer life cycle matrix of e. money/payment institutions was based on the concepts of various customer life cycle matrices.

These two customer groups are further explored in this study. The customer life cycle matrix and customer travel map are constructed based on the habits and characteristics of these customer groups. The customer life cycle matrix of e. money/payment institutions was based on the concepts of various customer life cycle matrices. After evaluating the research results, a customer life cycle matrix illustrating the life cycle of e. money/payment institution customers.

After preparing the customer life cycle matrix, it can be stated that e. money/payment institutions operating in Lithuania do not make critical mistakes, as a result of which they would lose customers en masse. Still, customers name a truly significant shortcoming after contractual service. In particular, there is a lack of clarity, precision, the number of service staff and customers complain about the speed of service and lack of languages. However, customers are generally satisfied with the day-to-day service.

Based on this customer life cycle matrix, it can be concluded that modern customers seek modern and intelligent services, so the choice of electronic money/payment institutions to advertise and serve customers only in the electronic space is available to customers in an appropriate and clear enough way. In the analysis phase, customers are interested in innovative services. Marketing content is usually visual and meaningful, so customers quickly decide to use the service. The acquisition stage by e. money/payment institutions runs smoothly due to the welldeveloped electronic registration; most goods or services are very quickly and conveniently available. Customers often start their contact with an organization with a quick registration on a website or gadget, and registration, in many cases, does not take long. More significant weaknesses in the management of electronic money/payment institutions are observed in the retention and loyalty phase. Customer problems are critical in the retention phase, which is the weakest point for electronic money / payment institutions due to the lack of clarity, customer service staff, and experience in customer service. The lack of expertise of organizations is also noticeable in the loyalty stage. Organizations do not offer long-term products, but this is also due to the novelty of the regulatory and legal environment. Also, an organization unable to retain a customer at the retention stage can find it challenging to maintain it at the loyalty stage. For example, suppose the customer did not contact the customer service staff during the retention phase and became loyal. In that case, the customer will likely be even more sensitive to problems during the loyalty phase because his expectations are high.

After analyzing the customer life cycle matrix, it can be concluded that customers' journey to the shopping stage in electronic money/payment institutions is 
smooth enough; the weakness of these institutions is the retention and loyalty stages. Following the customer travel matrix, a customer travel map was created to provide a clear, concise, and visualized survey result.

4 Table. Electronic user life cycle planning matrix (created by authors, based on Boag, 2018; Halvorsrud, Kvale, \& Følstad, 2016; Anderl, Becker, von Wangenheim, \&

Schumann, 2016; David C Edelman \& Singer, 2015; Barwitz \& Maas, 2018).

\begin{tabular}{|c|c|c|c|c|c|c|}
\hline $\begin{array}{l}\text { Indi } \\
\text { cato } \\
\text { rs }\end{array}$ & $\begin{array}{l}\text { Customer } \\
\text { life cycle } \\
\text { points }\end{array}$ & Discovery & Analysis & Acquisition & Retention & Loyalty \\
\hline $\begin{array}{l}\text { Task } \\
\text { s }\end{array}$ & & $\begin{array}{l}\text { Create } \\
\text { channels } \\
\text { that reach } \\
\text { users; } \\
\text { - Create } \\
\text { easy } \\
\text { accessibilit } \\
\text { y. }\end{array}$ & $\begin{array}{l}- \text { Create a } \\
\text { sense of trust } \\
\text { that } \\
\text { encourages } \\
\text { the use of } \\
\text { services; } \\
\text { - Create a } \\
\text { need. }\end{array}$ & $\begin{array}{l}\text { - Ensure that the } \\
\text { customer receives the } \\
\text { expectations of the } \\
\text { relevant product or } \\
\text { service } \\
\text { - Provide the customer } \\
\text { with the opportunity to } \\
\text { contact in case of } \\
\text { problems; } \\
\text { - Contact the customer } \\
\text { in case of problems. }\end{array}$ & $\begin{array}{l}\text { - Ensure smooth } \\
\text { communication } \\
\text { /problem } \\
\text { solving; } \\
\text { - Ensure clear } \\
\text { conditions and } \\
\text { rates }\end{array}$ & $\begin{array}{l}\text { Make } \\
\text { customers } \\
\text { loyal; } \\
\text { - Ensure as } \\
\text { few } \\
\text { problems as } \\
\text { possible or } \\
\text { good } \\
\text { service } \\
\text { when they } \\
\text { occur. } \\
\end{array}$ \\
\hline $\begin{array}{l}\text { Ques } \\
\text { tions }\end{array}$ & & $\begin{array}{l}- \text { How does } \\
\text { it work? } \\
\text { - What do } \\
\text { other } \\
\text { market } \\
\text { participants } \\
\text { offer? }\end{array}$ & $\begin{array}{l}\text { - How is it } \\
\text { different from } \\
\text { existing } \\
\text { service } \\
\text { providers? } \\
\text { - What are the } \\
\text { benefits? }\end{array}$ & $\begin{array}{l}\text { - How much will it } \\
\text { cost for the customer? } \\
\text { - Does the client need } \\
\text { it? } \\
\text { - Is it safe? } \\
\text { - Will the customer } \\
\text { remain satisfied? }\end{array}$ & $\begin{array}{l}\text { - Is it safe? } \\
\text { - Does the } \\
\text { customer trust? } \\
\text { - Will the } \\
\text { organization } \\
\text { meet customer } \\
\text { expectations? }\end{array}$ & $\begin{array}{l}- \text { How to } \\
\text { solve } \\
\text { problems or } \\
\text { issues? }\end{array}$ \\
\hline $\begin{array}{l}\text { Touc } \\
\text { hpoi } \\
\text { nts }\end{array}$ & & $\begin{array}{l}- \text { Social } \\
\text { media; } \\
\text { - Relatives, } \\
\text { friends, } \\
\text { acquaintanc } \\
\text { es; } \\
\text { - Press, } \\
\text { television, } \\
\text { radio. }\end{array}$ & $\begin{array}{l}\text { - Website; } \\
\text { - App; } \\
\text { - Social } \\
\text { networks; } \\
\text { - } \\
\text { Friends/relati } \\
\text { ves / } \\
\text { acquaintances }\end{array}$ & $\begin{array}{l}\text { - Social media; } \\
\text { - Pay per click; } \\
\text { - Payment options } \\
\text { based on card details. }\end{array}$ & $\begin{array}{l}\text { - Social media; } \\
\text { - App; } \\
\text { - Telephone } \\
\text { service; } \\
\text { E-mail service. }\end{array}$ & $\begin{array}{l}- \text { Social } \\
\text { media; } \\
\text { - App; } \\
\text { - Telephone } \\
\text { communica } \\
\text { tion; } \\
\text { - E-mail. }\end{array}$ \\
\hline \multirow{3}{*}{$\begin{array}{l}\text { Emo } \\
\text { tions }\end{array}$} & Gooc & & & & & \\
\hline & Medium & & & & & \\
\hline & $\mathrm{Bad}$ & & & & & \\
\hline $\begin{array}{l}\text { Wea } \\
\text { knes } \\
\text { ses }\end{array}$ & & $\begin{array}{l}\text { - Not all } \\
\text { potential } \\
\text { customers } \\
\text { are } \\
\text { available; }\end{array}$ & $\begin{array}{l}\text { - Lack of } \\
\text { consistency in } \\
\text { the pricing } \\
\text { system; } \\
\text { - Wide } \\
\text { variety and } \\
\text { change of } \\
\text { services. }\end{array}$ & $\begin{array}{l}\text { - Creating the right } \\
\text { conditions for the } \\
\text { client's needs } \\
\text { - Lack of clarity; } \\
\text { - The quality of the } \\
\text { product or service } \\
\text { received by the } \\
\text { customer. }\end{array}$ & $\begin{array}{l}\text { - Not able to } \\
\text { serve a large } \\
\text { flow of } \\
\text { customers; } \\
\text { - Lack of } \\
\text { clarity; } \\
\text { - Additional } \\
\text { services based } \\
\text { on customer } \\
\text { expectations. }\end{array}$ & $\begin{array}{l}\cdot \text { Lack of } \\
\text { customer } \\
\text { service } \\
\text { experience; } \\
\text { • } \\
\text { Customers } \\
\text { are usually } \\
\text { served in } \\
\text { English } \\
\text { only; } \\
\text { - Service } \\
\text { slow } \\
\text { enough. }\end{array}$ \\
\hline
\end{tabular}

The formed map allows determining that in the first stage of discovery of the customer journey map, three useful and necessary contact points are assigned to the selected customer group, which are specific to the selected customer group. The 
most attractive ways to discover this group of customers are social networks, gadgets, and websites. Next, the paper identifies departments that will help solve problems related to the discovery phase - marketing/e-marketing, design, and eshop management. These departments were chosen because, in the absence of customer experience with the organization, the brand image, prestige, functionality, and informativeness are essential to the consumer, and these qualities can be implemented through identified departments. After analyzing the customer experience, it can be stated that customers are satisfied during the discovery phase, so the research provides a recommendation for the discovery phase to follow innovations, maintain convenient gadget management, constantly update information on changes in all three listed channels.

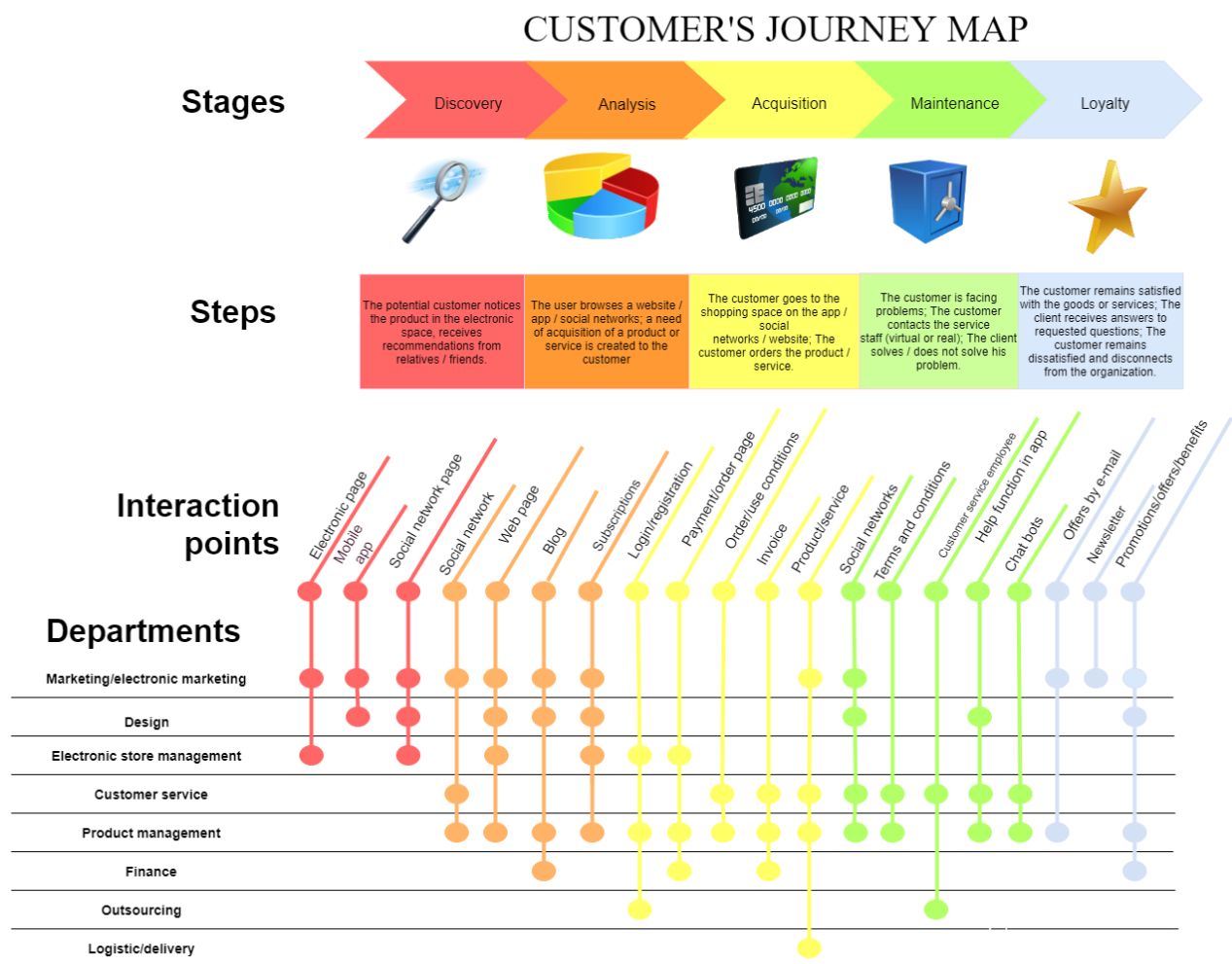

Fig. 2: Customer's journey map (created by authors based on the results of theoretical and empirical research and the matrix of customer life cycle)

The contact points identified in the analysis stage are social networks, website, blog, online subscriptions. The study determined that in the analysis phase e. money/payment institutions operate productively and purposefully. In the analysis stage, customers are quickly fascinated by the offered product or service; it is noticeable that the services are innovative and attractive. Therefore in the analysis 
stage, the recommendations of relatives/friends/acquaintances are significantly contributed, which are identified by respondents as the main reason for using these organizations. The departments identified at this stage are needed to solve problems or maintain quality services - marketing/e-marketing, design, e-shop management, customer service, product management, and finance departments. These departments are selected because the customer needs more information in the analysis phase than in the discovery phase, answering customer questions. Recommendations for this stage are to improve access and information to the customer constantly, interest the customer in new, market-missing services, and use as many channels as possible to facilitate the customer to receive information.

The contact points identified at the acquisition stage are login/registration, payment order page, terms of use, invoice, and product or service. At this stage, the investigation concluded that e. money/payment institutions operate efficiently. Most organizations that do not provide a physical product offer speedy and easy registration on their websites or gadgets, making the shopping phase of these establishments easy and accessible to customers. Organizations that offer a physical item, such as a debit or credit card, make it easy to pick up or receive the card by mail. During the acquisition phase, the departments that help solve the problems or maintain the quality of the product/service are identified - marketing/e-marketing, eshop management, customer service, product management, finance, logistics departments, and the possibility of hiring external staff. These departments are chosen because product acquisition is a susceptible stage that must ensure customer confidence in the organization. Marketing/e-marketing and store management departments provide clarity to the customer and accessible presentation of information. The customer service department helps the customer solve problems. The product management department responsible for service product quality assurance. The finance department is responsible for providing accurate and clear invoices to the customer. The logistics department is responsible for goods delivered to the customer. Hiring external staff can serve an organization with a lack of human resources to deliver the product, and so on. Recommendations for this phase are to adapt to innovation, create impeccable security for customers, keep payments easy and fast, and keep bills clear. Price stabilization and clarity is also a very high value for an organization.

In the maintenance phase, social networks, terms, and conditions, customer service employees, help functions in the app, "Chat bots" were identified. At this stage, this work analyzes the e. money/payment institutions face difficulties. Often, customer service staff can only serve in English, so such service is not suitable for all customers; these institutions face a lack of customer service staff or a lack of experience in customer service. The departments identified at this stage are marketing/e-marketing, design, customer service, product management departments, and outsourcing. The marketing department is responsible for the attractiveness of 
information, proper layout; the customer service department is crucial for its functionality to solve customer problems in real-time. The product management department is responsible for product or product quality after contract service. The possibility of hiring external staff can help those organizations that face a lack of experience in customer service. At this stage, the recommendations for organizations are to create clarity for the customer (where, in which case to apply, to publicize the channels that can be contacted), to implement innovations that can help in the absence of human resources, to expand the customer service department and service language range.

The contact points identified in the loyalty stage are e-mail, newsletters, promotions/offers, and benefits. It is crucial to provide the client with a sense of stability and peace to trust the organization. For this reason, customer service personnel are also critical, and all customer service channels are examined in the maintenance phase. For an organization to be loyal to the customer, the organization must ensure a high level of competitiveness against the incumbents in the market; the organization must provide high quality and long-lasting products. Therefore, e. money/payment institution organizations should broaden the range of services, taking into account the characteristics of the legal framework and the regulatory environment. The departments identified at this stage are the marketing/e-marketing, design, product management, and finance departments. These departments benefit from the attractive presentation of information, from new offer options to customers, and the finance department is responsible for providing clear and informative invoices to customers. Recommendations for this stage include improving the customer service system, offering long-term products to customers, offering promotions/discounts, and other tools needed to maintain a long-term customerorganization relationship.

\section{Conclusions}

Lithuania is witnessing a significant increase in the number of fintech companies. After analyzing the statistics, the number of notable fintech companies in Lithuania has been growing every year since 2013. Lithuanian fintech companies created 3400 additional high value-added jobs, and it is also noticeable that the existing Lithuanian fintech companies are Lithuanian capital. For these reasons, Lithuania was selected as a research object.

Multichannel access is a marketing and customer reach method that needs to be used for customers attraction, communication, and loyalty. There are a variety of digital channels that helps customers be attracted and turn communications faster and convenient.

More organizations use multichannel access in the 21 st century as a different channel is acceptable to each user. Moreover, most users use more than one channel to implement various functions of goods or services provided by an organization. 
However, a review of the scientific literature revealed a limitation of research in assessing multichannel access in the fintech sector. For this reason, the study organized by the author is focused on a specific and innovative sector.

The development of the customer life cycle matrix and the customer journey map revealed that significant errors in e-money/payment institutions were not indicated. However, the main shortcomings for customers are lack of security and clarity and the relatively slow and often only one-language service. Two groups of surveyed customers were selected to compile the concept of the customer journey map, which accounted for the largest share of respondents, namely 26-33-year-old men with higher education, living in a big city, earning a high income and 18-25 years old women with higher education, living in a big city, earning a high income. Based on these groups, a customer journey map was created and visualized. Providing a customer journey map identifies departments within the organization that can help maintain quality service or help solve a problem within the organization. It was found that the most common points of contact for the selected groups in the discovery phase are the website, social networks, mobile apps, and the departments that can correct the discovery phase errors discussed in study are marketing/emarketing, design, and e-shop management departments. The contact points identified for the selected customer groups in the analysis stage are social networks, websites, blogs, online subscriptions. Identified departments that can correct the mistakes discussed in work are marketing/e-marketing, design, e-shop management, customer service, product management, and finance departments. The contact points identified at the acquisition stage are login/registration, payment/order page, order and usage conditions, invoice, product/service. Identify error-correcting departments - marketing/e-marketing, e-shop management, customer service, product management, finance, and logistics departments, as well as external staff to correct errors. The contact points identified in the retention phase are social networks, terms and conditions, customer service staff, help functions in mobile apps, chatbots. Also, in this study, identified departments can correct the mistakes discussed in work - marketing/e-marketing, design, customer service, product management departments, and external staff. The contact points identified in the loyalty stage are e-mail offers, newsletters, promotions/offers/benefits. Identify error-addressing departments - marketing/e-marketing, design, product management, and finance departments.

The analysis of the scientific literature revealed the limitations of the scientific literature and research in assessing multichannel access and customer journey mapping in specific and innovative sectors. For this reason, a study was organized, focusing specifically on one sector-specific area of customer journey and customer communication channels. The research focuses on the innovative and constantly changing fintech sector, about which specific scientific approaches and evaluation methods have not yet been established in the scientific literature. This scientific 
article can be used in e-money/payment institutions to create an individual customer journey map and understand the benefits and multichannel access in the fintech sector.

When evaluating further research directions, it is recommended to make customer journey maps and analyze the application of multichannel access in other areas of fintech, such as savings and investment, lending, financial planning, etc.

\section{References}

Abel, T., \& McQueen, D. (2020). The COVID-19 pandemic calls for spatial distancing and social closeness: not for social distancing. International Journal of Public Health, 65(3), 231

Addis, M. (2016). Understanding the Customer Journey to Create Excellent Customer Experiences in Bookshops. International Journal of Marketing Studies, 8(4), 20.

Anderl, E., Becker, I., von Wangenheim, F., \& Schumann, J. H. (2016). Mapping the customer journey: Lessons learned from graph-based online attribution modeling. International Journal of Research in Marketing, 33(3), 457-474.

Barwitz, N., \& Maas, P. (2018). Understanding the Omnichannel Customer Journey: Determinants of Interaction Choice. Journal of Interactive Marketing, 43, 116-133.

Boag, P. (2018). What Is Customer Journey Mapping and How to Start? Retrieved April 8, 2019, from https://boagworld.com/audio/customer-journey-mapping/

Bolton, R. N., Parasuraman, A., Hoefnagels, A., Migchels, N., Kabadayi, S., Gruber, T., Solnet, D. (2013). Understanding Generation Y and their use of social media: a review and research agenda. Retrieved from https://dspace.lboro.ac.uk/

Bruce, B. D. (2010). Mapping the Customer Journey. Retrieved from www.forrester.com.

Buijs, J. C. A. M., Bergmans, R. F. M., \& Hasnaoui, R. El. (2019). Customer journey analysis at a financial services provider using self service and data hub concepts.

Chaffey, D., \& Ellis-Chadwick, F. (2019). Digital Marketing Seventh Edition. Retrieved from https://books.google.lt/books?hl=lt\&lr=\&id=1yGDwAAQBAJ\&oi=fnd\&pg=PT20\&dq=chaffey+marketing\&ots=XhWp3XmR_7\&sig= Wv5WdMoLXq9WxA7mMvDwh9tcPAc\&redir_esc=y\#v=onepage\&q=chaffey marketing \& $\mathrm{f}=$ false

Christi, S., \& Barberis, J. (2016). The FinTech Book. https://doi.org/10.1002/9781119218906. 
Cowman, S. (2018). How to structure an effective multichannel marketing plan. Retrieved April 5, 2019, from https://www.smartinsights.com/online-brand-strategy/multichannelstrategies/structure-effective-multichannel-marketing-plan/

Edelman, Dadiv C., \& Singer, M. (2015). Competing on Customer Journeys. Harward Business Review. Retrieved from http://www.ritalka.com/secured_docs/Ritalka Training Tab/Learn - Educate - Lead Library/Competing on Customer Journeys.pdf

EY. (2019). Global FinTech Adoption Index. Retrieved from https://assets.ey.com/content/dam/ey-sites/ey-com/en_gl/topics/banking-and-capitalmarkets/ey-global-fintech-adoption-index.pdf

Halvorsrud, R., Kvale, K., \& Følstad, A. (2016). Improving service quality through customer journey analysis. Journal of Service Theory and Practice, 26(6), 840-867.

Hwang, Y., Lin, H., \& Shin, D. (2018). Knowledge system commitment and knowledge sharing intention: The role of personal information management motivation. International Journal of Information Management, 39, 220-227.

Invest Lithuania. (2019). The Fintech Landscape in Lithuania 2018 Report.

Invest Lithuania. (2021). The Fintech Landscape in Lithuania.

Iskandar, M. S., \& Komara, D. (2018). Application Marketing Strategy Search Engine Optimization (SEO). IOP Conf. Ser.: Mater. Sci. Eng, 407, 12011. https://doi.org/10.1088/1757-899X/407/1/012011

Key, T. M. (2017). Domains of Digital Marketing Channels in the Sharing Economy Economy. Journal of Marketing Channels, 24(1-2), 27-38.

Lassoued, Z., Alhendawi, M., \& Bashitialshaaer, R. (2020). An Exploratory Study of the Obstacles for Achieving Quality in Distance Learning during the COVID-19 Pandemic. Education Sciences, 10(9), 232.

Lemke, F., Clark, M., \& Wilson, H. (2011). Customer experience quality: an exploration in business and consumer contexts using repertory grid technique. Journal of the Academy of Marketing Science, 39(6), 846-869.

Liu, D., \& Yang, C. (2016). Media Niche of Electronic Communication Channels in Friendship: A Meta-Analysis. Journal of Computer-Mediated Communication, 21(6), 451466.

Moon, H., Han, S. H., Chun, J., \& Hong, S. W. (2016). A Design Process for a Customer Journey Map: A Case Study on Mobile Services. Human Factors and Ergonomics in Manufacturing \& Service Industries, 26(4), 501-514. 
Nenonen, S., Rasila, H., Junnonen, J.-M., \& Karna, S. (2010). Customer Journey-a method to investigate user experience.

<https://pdfs.semanticscholar.org/bb0a/a5d373c8011eeca2b8b07638ab25c2baec31.pdf>

Pantano, E., \& Viassone, M. (2015). Engaging consumers on new integrated multichannel retail settings: Challenges for retailers. https://doi.org/10.1016/j.jretconser.2015.04.003

Peterson, M., Gröne, F., Kammer, K., \& Kirscheneder, J. (2010). Multi-Channel Customer Management Delighting Consumers, Driving Efficiency. Retrieved from https://www.strategyand.pwc.com/media/uploads/Multi-

Channel_Customer_Management.pdf

Rhee, E. (2009). Multichannel management in direct marketing retailing: Traditional call center versus internet channel. Journal of Database Marketing \& Customer Strategy Management, 17(2).

Rosenbaum, M. S., Otalora, M. L., \& Ramírez, G. C. (2017). How to create a realistic customer journey map. Business Horizons, 60(1), 143-150.

Sahay, R., Eriksson von Allmen, U., Lahreche, A., Khera, P., Ogawa, S., Bazarbash, M., \& Beaton, K. (2020). The Promise of Fintech- Financial Inclusion in the Post COVID-19 Era. Retrieved from https://books.google.lt/books?hl=lt\&lr=\&id=UqwYEAAAQBAJ\&oi=fnd\&pg=PR7\&dq=fin tech+in+covid-19+era\&ots=YhgrJghwd8\&sig=MH9x0sMAn_zv-NyXL0Q0-

FHM3cE\&redir_esc $=\mathrm{y} \# \mathrm{v}=$ onepage $\& \mathrm{q} \& \mathrm{f}=\mathrm{false}$

Statista. (2020). Global consumer fintech adoption rates 2015-2019, by category. Retrieved from https://www.statista.com/statistics/1055356/fintech-adoption-rates-globally-selectedcountries-by-category/

The Vomela Companies. (2017). Making sense of Multichannel Marketing. Retrieved from https://www.elkgrovegraphics.com/wp-content/uploads/2017/06/VOM-MKT_MultiChannel_v07.pdf

Voorhees, C. M., Fombelle, P. W., Gregoire, Y., Bone, S., Gustafsson, A., Sousa, R., \& Walkowiak, T. (2017). Service encounters, experiences and the customer journey: Defining the field and a call to expand our lens. Journal of Business Research, 79, 269-280. 